\title{
THE PRINCIPLE OF LEGALITY OF THE TAXES: AN EVALUATION ON TURKEY AND THE SELECTED COUNTRIES
}

Murat DEMiR ${ }^{1}$

\author{
Rıdvan ÖNDER ${ }^{2}$
}

\begin{abstract}
In this study; The emergence and development of the principle of legality of taxation and how the principle of legality of taxation affects the taxation authority will be studied in Turkey and selected countries. The study also examines the modern financial systems based on the principle of legality of taxation. The administrative discretion has limited in these financial systems and all procedures related to the tax technique are shaped on the basis the principle of legality of taxation. The social and economic texture that enables the functioning of this financial structure is also examined. Similarly, countries where the principle of legality of taxation is controversial will be examined with structural difficulties related to social and economic structure in these countries.
\end{abstract}

Keywords: The Principle Of Legality Of Tax, Democracy, Tax Democracy Relations, The Effect of Principle Of Legality Of Tax on Social and Economic Structure.

JEL Code: H20, K34, D72.

\section{Introduction}

The unlawfulness of taxation and the lack of any legal limitation have caused various events in history. The Magna Carta Libertatum (1215), which is considered as the basis of the principle of legality of taxation and the first known document in this regard, throughout the history.

In this study, the historical development of the principle of legality of taxation, which started with Magna Carta Libertatum and significant developments in different countries has been discussed. In addition, the effects of these events on democracy were examined and it was emphasized whether the principle of legality of taxation had effects on the economic and social structures of the states and what results. In countries that adopt the principle of the legality of taxation, taxation-related violence and so on. it is possible to say that social events disappeared. The democratic structure has been strengthened and developed rapidly by ensuring the functioning of the principle of the legality of taxation.

The principle of the legality of taxation has affected the social, political and economic rights of the society and provided a social compromise between the state and the society. The main reason for this is; In democratic societies, those who act contrary to the principle of the legality of taxation or those who make unbalanced taxation have heavy legal responsibilities. Undoubtedly, the principle of the legality of the taxation is not possible to be provided by the constitutions alone. Democratization movements must act in parallel. Developed countries,

\footnotetext{
1 Prof. Dr., Harran University Department of Public Finance, m.demir@harran.edu.tr

2 Asst. of Tax Inspector, Republic of Turkey Ministry of Treasury and Finance, PhD Student, Ankara University Institute of Social Sciences, ridvan.onder@vdk gov.tr, (corresponding author)
} 
which can realize this harmony, provided their economic structures with institutional identity, reduced their unregistered economies to low levels, and strengthened their social, economic and political structures by ensuring justice in income distribution and taxation.

\section{The Historical Development of The Principle of the Legality of Taxation}

Magna Carta states that essentially unauthorized tax collection is not possible. According to Magna Carta, the King cannot impose taxes when he wishes, and when a new tax is imposed, those who will pay the tax vote. This rule was then based on many freedom and independence struggles. When taxpayers faced heavy and arbitrary tax burdens, they struggled with support from this rule.

In the following periods, in other countries, papers and contracts with reference to the Magna Carta were prepared and implemented (David, 1999: 370-371; Akdoğan, 2009: 198). Some of these are as follows.

The Petition of Rights and Bill of Rightsin the UK in 1627 and 1689, the Declaration of Independence, which began with the revolt of the Tea Taxes of England in the Americas and declared in 1776, the Declaration of Human Rights published in 1789, following the French Revolution, signed in 1808 in the Ottoman Empire the charter of alliance, the Universal Declaration of Human Rights adopted by the United Nations in 1948, can be cited as an example (Öncel et. al., 1985: 47). All these agreements regulate the financial relations between the state and the individual and determine the legal and institutional nature and framework of mutual powers and responsibilities.

\section{Importance of the Principle of Legality of Taxation and Its Effect on Democratic Structure}

Many historical and social events have been guided by the principle of legality of taxation. Some of the developments in this study are discussed. The historical and social events that have guided the principle of the legality of taxation have led to a number of effects on the social and economic structure in each country. The nature and depth of these effects were also investigated.

With the Magna Carta Agreement held in England in 1215, the issue of obtaining tax collection authority from the law is accepted as undisputed. Thus, the principle of the legality of taxation the most important one of the principles of taxation, was accepted by the king. In the first period, there were some problems in the applicability of this agreement. However, it is seen in the constitution of many countries that the principle of the legality of taxation is a fundamental necessity. In this context, Magna Carta has been the main reference point for the principle of the legality of the taxation included in many constitutions. When we look at the past history of states and societies, it is seen that big rebellions and struggles for independence have emerged as a result of arbitrary arrangements, regardless of a specific legal rule. (Vanistendael, 1996; 1). Resistance to injustice and inequality in taxation has soon turned into tax revolts and then mass struggles. For this reason, placing the principle of the legality of the taxation by preventing arbitrariness in taxation has a special importance among the principles of taxation.

In almost all countries, the principle of the legality of taxation is guaranteed by the provisions of the founding constitutions of the countries concerned. The constitutions have disciplined the political authorities in a way by drawing the legal framework of the issues related to taxation. In 
the later periods, the institutional nature of the relationship between the state and the taxpayer has gained even more depth with the principles of taxation formed by taking the spirit from the constitutions (Smith, 2014: 30-31; OECD, 2014).

The principle of the legality of the taxation after the historical and social events has become a principle that must be included in the constitutions, as well as a secret social consensus between the state and the individuals. Accordingly, the principle of the legality of taxation guarantees the rights of individuals on the one hand. on the other hand, individuals also grant a taxation to individuals and parties to bring to power or to hand over the state to the government. This authorization does not only imply the collection of taxes on the basis of law. It also includes the authority of public expenditure these taxes. In this respect, those who come to elections are entitled to both the taxation authority and the authority of public expenditure

According to the principle of the legality of the taxation, the authority to impose taxes and similar financial obligations has been undertaken by the legislative body or the authority has been granted to this body by the people. It can be said that authority is not given to the executive body in particular. It can be stated that it is important to give this authority to the legislature where almost all sections of the society are accepted and represented because the executive organ may reflect the views of a certain segment and may not be fair, and that it is important for the results to be adopted by the whole society. This basic approach, of course, will contribute to the institutionalization and development of the democratic functioning in the country.

The legal nature of the taxation authority has changed over the history according to the state understanding. However, in today's modern state, the authority of taxation is based on state sovereignty. So the basic question is, how does state sovereignty work? In modern systems where state sovereignty is essential, it is not possible to implement this authority in an absolute and unlimited manner. The main thing here is the principle separation of powers. Legislative and judicial powers control the execution by discipline. it has a democratic functioning with all its bodies and functionality.

Governments collect taxes from taxpayers and realize public expenditures. In doing so, they must take into account the demands of the society and thus the taxpayers. Politicians who do not use these powers in a lawful way or who do not use them for the benefit of the electorate will be removed from the power by the people who choose them again. $\mathrm{n}$ the first elections, the people have the right to give their powers of taxation and spending to another power. in this context, we can say that the principle of the legality of taxation actually finances the functioning of the democratic structure. When voters think that there is an injustice in taxation, they can give the power to collect tax immediately to another political power. In this context, it can be said that the legality principle of the tax alone is limited. The principle of the legality of taxation has the chance to be applied in a much stronger and more effective manner in countries where democracy, politics, law and economic structure are institutionalized.

The principle of the legality of taxation enters into the constitutions of most countries governed by a democratic and parliamentary regime. Of course, it is important that this principle, which is indispensable for the society, takes place in the constitutions. But how this principle is interpreted and applied by the state and society is much more important. This situation can be handled in terms of developed and developing countries. Due to the social events in developed countries, the desire for unlimited taxation of power has disappeared with time. Instead, taxpayer focused taxation principles such as justice and certainty in taxation were in question. Regarding the 
situation in developing countries, it can be seen that most of the principle of the legality of the taxation cannot be applied in a strong manner. The principle of the legality of taxation is symbolic in the constitutions of many developing countries. Inequality in taxation, inequality in distribution of income and tax awareness and public finance problems are problematic in every period.

\section{Conclusion}

To summarize the principle and scope of the legality of the taxation; The principle of the legality of the taxation is a multifaceted constitutional principle that influences many areas such as the development of democracy, the clarity of the tax, the spread of the tax on the base, taxation according to the financial power of all, the generality of the tax, the clarification of exceptions and exemptions, and the strengthening of the constitutional order.

The emergence and development of the principle of the legality of tax has been parallel to the development and institutionalization of democracy in many western countries and there is a close relationship between them. In this respect, the principle of the law of democratization of societies and the legality of taxes can be identified. the government uses the authority to collect taxes and public spending on behalf of the nation. Through elections, which are indispensable elements of democracy, society gives this power to whom it wishes. In this context, it is expected that the governments that care about the principle of the legality of taxation will be more successful in the elections.

The principle of the legality of taxation leads to the institutionalization of the state and the democratic structure, and affects the socio-economic dynamics of the society in different ways. In the economies where these principles are blended with democracy, positive data are obtained in macro and microeconomic indicators and it is seen that there is equality in taxation, determination and income distribution among citizens.

The principle of the legality of taxation is a culture that will develop together with democratic development. Where democratic rules and institutions are not sufficiently institutionalized, the principle of the legality of taxation is far from meeting the expectations of the parties. he principle of the legality of the tax is a kind of social agreement between the state and the taxpayers who protect the citizenship against the state, draws the limits of the state's taxation authority, and provides the state with the resources that will enable the state to fulfill its responsibilities. Political decisions and behaviors that are contrary to this agreement or which do not satisfy the voters will result in the abolition of the elected. Preserving this principle has had positive results in most of the developed countries and has had positive effects on social, economic and political structure. 


\section{References}

Journals/Periodicals:

İlal, E., (1968). “Magna Carta” istanbul Üniversitesi Hukuk Fakültesi Mecmuası, 34 (1-4), pp. 210-242.

\section{Books:}

Akdoğan, A., (2009). Kamu Maliyesi, Ankara, Gazi Kitabevi.

David N. H., (1999). Public Finance, New York, The Dryden Press.

Öncel, M., Çağan, N., \& Kumrulu, A., (1985). Vergi Hukuku, Ankara Üniversitesi Siyasal Bilgiler Fakültesi Yayınları, Ankara.

Smith, A., (2005). "An Inquiry into The Nature and Causes of The Wealth of Nations" An Electronic Classics Series Publication, England.

\section{Edited Books;}

Vanistendael, F., (1996). Tax Law Design and Drafting, Chapter 2, Legal Framework for Taxation (volume 1; International Monetary Fund: 1996; Victor Thuronyi, ed.), pp. 1-56.

\section{Thesis:}

Güneş, G., (1992). “Verginin Yasallığı İlkesi”, Doktora Tezi, İstanbul Üniversitesi Hukuk Fakültesi, İstanbul.

\section{Internet Sources:}

Organisation for Economic Co-operation and Development. (2014). Addressing The TaxChallenges of The Digital Economy, içinde "Fundamental Principles of Taxation", s.30-31 OECD 2014, http://www.oecd.org/ctp/addressing-the-tax-challenges-of-the-digital-economy9789264218789-en.htm, (21.04.2019). 